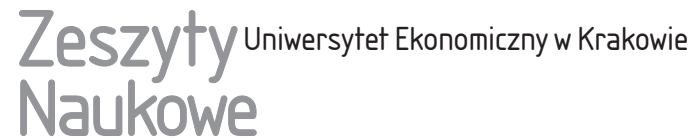

\section{Płynność finansowa jako istotne kryterium oceny przedsiębiorstwa}

\section{Streszczenie}

Artykuł dotyczy płynności finansowej rozważanej jako istotny miernik oceny działania przedsiębiorstwa. Płynność finansowa jest konsekwencją kształtowania właściwych relacji wpływów do wydatków w procesie zarządzania. Jej istotę, sposoby określania i analizę przedstawiono na podstawie bilansu i rachunku przepływów pieniężnych, omawiając wskaźniki płynności i ich klasyfikację oraz dokonując ich interpretacji. Badanie płynności w polskich firmach oparto na jednostkowych sprawozdaniach finansowych PKN Orlen SA za lata 2013-2016. Dokonano analizy przepływów pieniężnych oraz statycznych i dynamicznych wskaźników płynności. Metodami badawczymi były studia literaturowe na temat sprawozdawczości, płynności i analizy finansowej, interpretacja właściwych aktów prawnych, analiza sprawozdań finansowych oraz wnioskowanie. Wyniki badań potwierdzają, że płynność finansowa jest obecnie najważniejszym kryterium oceny przedsiębiorstwa, zapewniającym jego równowagę i stabilność.

Słowa kluczowe: płynność finansowa, przepływy pieniężne, wskaźniki płynności, ocena przedsiębiorstwa.

Klasyfikacja JEL: M21, M41.

\section{Wprowadzenie}

Płynność finansowa jest obecnie uważana za jeden z najważniejszych parametrów oceny przedsiębiorstwa. Jest ona istotna zarówno dla menedżerów dążących do zwiększania wartości akcji firmy, jak i dla inwestorów oczekujących na taki

Ewa Wiktoria Babuśka, Uniwersytet Ekonomiczny w Krakowie, Wydział Finansów i Prawa, Katedra Rachunkowości Finansowej, ul. Rakowicka 27,31-510 Kraków, e-mail: babuskae@uek.krakow.pl 
wzrost ${ }^{1}$. Wartość tę determinują przyszłe przepływy pieniężne i powinny być one poprzedzone działaniami powodującymi ich maksymalizację (Brigham i Houston 2015, s. 66). Wszystkie przyszłe przepływy pieniężne są więc szacowane i dyskontowane celem ustalenia ich wartości bieżącej. Wartość stopy dyskontowej jest tożsama z kosztem kapitału oraz stanowi ocenę ryzyka przyszłych przepływów pieniężnych. Płynność finansowa wyraża zdolność przedsiębiorstwa do spłaty zobowiązań bieżących, czyli krótkoterminowych, w wyznaczonych terminach, a tym samym pozwala określić sytuację finansową oraz sposób zarządzania wpływami i wydatkami pieniężnymi. Płynność finansową można ustalić, przeanalizować i ocenić na podstawie informacji wykazywanych w sprawozdaniach finansowych przedsiębiorstw.

Celem artykułu jest przedstawienie istoty płynności finansowej oraz sposobów jej kwantyfikowania na podstawie bilansu i rachunku przepływów pieniężnych, a także wskazanie jej rangi i funkcji jako istotnego kryterium oceny przedsiębiorstwa. Zdefiniowano płynność finansową, a także omówiono dane sprawozdawcze wykorzystywane do obliczania wskaźników płynności oraz dokonano ich klasyfikacji i interpretacji. W części badawczej zaprezentowano informacje niezbędne do obliczenia i analizy płynności finansowej w sprawozdaniach polskich przedsiębiorstw, wykorzystując jednostkowe sprawozdania finansowe Polskiego Koncernu Naftowego Orlen SA za lata 2013-2016. Dokonano oceny przepływów pieniężnych oraz analizy wskaźników płynności w ujęciu statycznym i dynamicznym. Wykazane w tabelach dane liczbowe porównano w czasie oraz uzupełniono komentarzami. Zastosowanymi metodami badawczymi są studia literaturowe w obszarze sprawozdawczości, płynności i analizy finansowej, analiza zakresu i treści elementów sprawozdań finansowych pod kątem płynności finansowej z uwzględnieniem interpretacji właściwych aktów prawnych, jak również studium przypadku oraz wnioskowanie.

${ }^{1}$ Informacja na temat płynności jest poszukiwana przez większość interesariuszy, w tym zwłaszcza przez kontrahentów i inwestorów, ale może być adresowana do różnych grup odbiorców i użytkowników sprawozdania finansowego. Znajomość podstawowych wskaźników płynności powinna być priorytetem również dla menedżerów podejmujących ważne decyzje zarządcze dotyczące przyszłości firmy i możliwości jej dalszego działania w warunkach stabilnej sytuacji finansowej gwarantującej terminową spłatę zobowiązań. Płynność finansowa jest ważna dla właścicieli firmy (akcjonariuszy, udziałowców) oczekujących wypłaty dywidendy z tytułu prawa własności i zainwestowanych środków. 


\section{Istota płynności finansowej przedsiębiorstwa}

Płynność finansowa określana jest jako zdolność przedsiębiorstwa do regulowania bieżących zobowiązań ${ }^{2}$. Płynność finansową (krótkookresową) należy odróżniać od wypłacalności przedsiębiorstwa, wyrażającej się zdolnością do sfinansowania długów skumulowanych posiadanymi aktywami i nazywanej w literaturze przedmiotu długoterminową płynnością finansową lub równowagą dochodową. Równowagę taką zapewniają znacząco wyższe wpływy niż łączne wydatki w długim okresie działalności jednostki, choć nie zawsze oznacza to występowanie płynności finansowej w krótkim okresie. Wyróżnia się też płynność majątku, czyli możliwość spieniężenia danego składnika aktywów, przy czym szybkość zamiany na środki pieniężne jest czynnikiem wyznaczającym płynność finansową (Sierpińska i Jachna 2004, s. 145-146).

Płynność finansowa odnosi się do perspektywy krótkookresowej, a wypłacalność do perspektywy długookresowej, natomiast stopień płynności składnika aktywów zależy od łatwości i szybkości zamienienia go na gotówkę (Golej i Prędkiewicz 2015, s. 156).

Płynność finansowa jest pojęciem różnie definiowanym. W najprostszym ujęciu oznacza zdolność do regulowania bieżących zobowiązań, a jej zachowanie jest uznawane za podstawowy warunek działania przedsiębiorstwa. Najczęstsze rozumienie płynności finansowej odwołuje się do wypłacalności przedsiębiorstwa, czyli do możności spłacania zobowiązań powiązanych ze zwykłymi operacjami, nieoczekiwanymi zdarzeniami czy sytuacjami umożliwiającymi wykorzystanie nadarzających się okazji do zakupu produktów. Funkcjonuje też pojęcie płynności związane z wymienialnością jednych aktywów na inne, określane jako łatwość realizowania transakcji wymiany przy występujących niskich kosztach transakcyjnych (Michalski 2015, s. 38).

Płynność finansowa ma zastosowanie w zarządzaniu wpływami i wydatkami przedsiębiorstwa w celu równoważenia ich wysokości oraz usuwania skutków zakłóceń w regularnym i zsynchronizowanym strumieniu ich przepływów z posiadanej rezerwy środków pieniężnych. Stan środków pozwalający finansować ogół zobowiązań, niezależnie od terminów ich spłat, nie jest jednak wymagany ani gospodarczo uzasadniony. Utrzymanie płynności finansowej może też zapewniać kredyt krótkoterminowy. Sposób zapłaty powinien mieć uzasadnienie w rachunku ekonomicznym, dzięki któremu można przeanalizować, czy koszt utraconych korzyści związany z nieangażowaniem środków w działalność przewyższy koszt

2 Zobowiązania bieżące podlegają zapłacie w ciągu 12 miesięcy od dnia bilansowego i obejmują zobowiązania wymagalne, tj. z określonym terminem zapłaty, oraz inne zobowiązania, z niepewnym lub niedokładnie określonym terminem zapłaty (m.in. Ustawa z dnia 29 września 1994 r. ..., art. 3, ust. 1, pkt 22). 
kredytu, a także czy rezultaty wydatkowania pieniędzy z zaciągniętego kredytu będą większe od kosztów jego obsługi (Dudycz 2011, s. 55).

Posiadanie płynności finansowej jest wynikiem zachowania równowagi pomiędzy wydatkami a wpływami. Wpływy mogą być osiągane z różnych źródeł, przede wszystkim ze spłat należności od odbiorców za sprzedane im wyroby, towary i usługi. Pożądany poziom płynności finansowej można także osiągnąć przez sprzedaż składników majątku o wyższej wartości, czyli zmniejszenie sumy płynnych aktywów ${ }^{3}$. Wiąże się to $\mathrm{z}$ dodatkowymi kosztami i utratą możliwych przyszłych korzyści ekonomicznych z tytułu eksploatacji takich aktywów. W definicjach płynności finansowej obok konieczności niezwłocznej zapłaty bieżących zobowiązań z istniejącej puli środków pieniężnych lub pozostałych aktywów łatwych do spieniężenia podkreśla się także zdolność finansowania nieoczekiwanych wydatków na realizację zakupów różnych produktów (Podstawy finansów... 2015, s. 158-159).

Płynność finansowa oznacza trwałą zdolność do spłacania bieżących zobowiązań, a wyróżniana dodatkowo tzw. bieżąca płynność finansowa wyraża zdolność do spłaty zobowiązań w wyznaczonych terminach. W najprostszym ujęciu płynność finansowa jest zdolnością płatniczą. Porównanie płynności z rentownością (dzięki której mierzy się wielkość dochodów firmy) wskazuje na prymat płynności, ponieważ jej utrzymanie warunkuje sprawność działania i wiarygodność przedsiębiorstwa. Główną przyczyną upadku przedsiębiorstw nie jest bowiem brak zysku, lecz utrata płynności finansowej ${ }^{4}$. Posiadana rentowność przy braku płynności finansowej może w krótkim okresie nie zabezpieczyć przedsiębiorstwa przed niewypłacalnością i upadłością. Płynność finansowa stanowi gwarancję solidności firmy w jej stosunkach z kontrahentami. Utrzymywanie płynności według wskaźników normatywnych leży w gestii kierownictwa, a śledzenie jej poziomu jest obowiązkowe. Skuteczne i efektywne działanie przedsiębiorstwa jest konsekwencją optymalnego, a nie coraz wyższego (zmierzającego do maksimum) poziomu płynności finansowej. Niebezpieczeństwem jest nie tylko utracenie płynności, ale i dopuszczenie do wystąpienia nadmiernej ilości pieniędzy, czyli do

3 Aktywa płynne to składniki majątku podlegające obrotowi na aktywnym rynku, dzięki czemu mogą być szybko sprzedane za gotówkę według ceny rynkowej, bez dokonywania znacznej obniżki ich ceny (Brigham i Houston 2015, s. 115).

${ }_{4}^{4}$ Jak podaje D. Wędzki, z badań w krajach rozwiniętych wynika m.in., że upadłość ok. 80\% przedsiębiorstw w Wielkiej Brytanii spowodowana była utratą płynności finansowej, a nie stratą netto. Płynność finansowa determinuje też byt polskich przedsiębiorstw, co potwierdzają pośrednio badania tego autora nad upadłościami spółek akcyjnych (ok. 80\% prawidłowych modelowych wskazań prognozujących upadłość lub jej brak zależy tylko od wskaźników wypłacalności krótko- i długoterminowej). Także analiza kilkudziesięciu modeli upadłości dla gospodarki polskiej dokonana przez B. Prusaka wykazała, że wskaźniki płynności finansowej należą do najczęściej wykorzystywanych w tych modelach i wskaźnikom tym przypisywana jest najwyższa waga (Wędzki 2015, s. 129). 
nadpłynności. Fakt utrzymywania przez przedsiębiorstwo niskiego poziomu płynności może sygnalizować trudności z realizacją bieżących płatności, a poziomu wysokiego - brak wydajności w użytkowaniu zasobów i zamrażanie środków pieniężnych, co powoduje obniżenie rentowności (Wąsowski 2011, s. 29-35).

Analiza płynności finansowej koncentruje się na sposobie osiągania zdolności przedsiębiorstw do honorowania swoich zobowiązań o terminie kwalifikowalności krótszym niż rok oraz aktualnych długów, które muszą być pokryte z aktywów o podobnym terminie transformacji w postać płynną. Wśród czynników kształtujących płynność finasową można wyróżnić: domenę działalności, stopień dojrzałości przedsiębiorstwa i jego wielkość, sezon działalności, sytuację ekonomiczną, strukturę aktywów, strukturę aktywów bieżących i szybkość ich rotacji, strukturę finansową (Costea i Hostiuc 2009, s. 252).

Celem analizy płynności finansowej jest określenie możliwości wywiązywania się przedsiębiorstwa z zaciągniętych zobowiązań bieżących w ustalonych terminach spłaty i ocena posiadania adekwatnej dla niego płynności finansowej, czyli dysponowania właściwymi zasobami środków pieniężnych, zabezpieczającymi dokonywanie spłat bieżących. Wynikiem analizy płynności finansowej jest prawidłowe ocenienie aktualnego stanu finansowego przedsiębiorstwa i nakreślenie możliwości jego rozwoju. Do analizy i oceny płynności służą wskaźniki płynności, które pozwalają zorientować się w możliwościach spłaty przez przedsiębiorstwo zadłużenia z terminem zapadalności do jednego roku. Wskaźniki płynności pomagają uzyskać odpowiedź na pytanie, czy przedsiębiorstwo będzie mogło uregulować swoje zobowiązania w terminie oraz czy utrzyma zdolność operacyjną. Odpowiedź negatywna na to pytanie oznacza, że płynność finansowa jest jedną z kwestii wymagających niezwłocznego rozstrzygnięcia (Brigham i Houston 2015, s. 114).

Płynność stanowi zjawisko dynamiczne, nacechowane dużą częstotliwością zmian miar jej wielkości. Nawet niewielkie wahania wielu różnych czynników płynności mogą doprowadzić do okresowej utraty zdolności płatniczej przez przedsiębiorstwo. Utrzymywanie właściwej płynności finansowej jest conditio sine qua non zapewnienia ciągłości działania przedsiębiorstwa (Podstawy finansów... 2015, s. 159, 184).

Płynność musi podlegać ustawicznemu śledzeniu, badaniu i ocenianiu, szczególnie pod kątem wpływów środków pieniężnych oraz wielkości i racjonalności wydatków, jak również powiązań majątku i kapitałów celem ustalenia możliwości i perspektyw spłaty w terminie wymaganych zobowiązań (Gabrusewicz 2014, s. 331).

Analiza płynności ma znaczenie w ocenie możliwości kontynuacji działalności przez jednostki. Decyzje podejmowane przez zarządy przedsiębiorstw muszą być uwarunkowane rzetelną oceną skutków różnych działań, a najistotniejsza 
jest sfera finansów, która przesądza nie tylko o istnieniu jednostki, ale też o jej rozwoju. Uznając płynność finansową za główny stymulator działalności przedsiębiorstw, ich zarządy dążą do formowania właściwych relacji pomiędzy płynnością a rentownością, bo to one decydują o powodzeniu firmy i mogą rzutować na wzrost jej wartości. Kwestia płynności finansowej musi być uwzględniana w decyzjach krótko- i długoterminowych.

W opracowaniach powstałych w następstwie kryzysu z 2008 r., uznawanego de facto przez część ekonomistów za kryzys płynności (Costea i Hostiuc 2009, s. 252), starano się przeanalizować relacje między zarządzaniem płynnością a rentownością przedsiębiorstw. W pracy (Owolabi i Obida 2012) zmierzono te relacje, wykorzystując dane wybranych firm produkcyjnych notowanych na giełdzie w Nigerii. Wynik badania uzyskano na podstawie analizy opisowej - wykazano, że zarządzanie płynnością finansową przy uwzględnieniu polityki kredytowej firm, zarządzania przepływem środków pieniężnych i cyklem konwersji gotówki wpływa znacząco na rentowność przedsiębiorstw. Stwierdzono, że zarządy firm mogą zwiększać rentowność, stosując właściwą politykę kredytową, krótki cykl konwersji gotówki oraz skuteczne procedury zarządzania przepływem środków pieniężnych (Owolabi i Obida 2012, s. 10).

\section{Statyczne i dynamiczne badanie płynności finansowej}

\subsection{Uwagi ogólne}

Płynność finansowa jest jedną z podstawowych miar oceny działalności finansowej przedsiębiorstwa. Rozpatruje się ją w dwóch ujęciach:

- statycznym, odzwierciedlającym sytuację w określonym momencie, np. dniu, na który sporządza się sprawozdanie finansowe; takim elementem sprawozdania jest bilans, ukazujący stan majątku i kapitałów przedsiębiorstwa na dany dzień, w tym wynik finansowy (zysk lub stratę) przeniesiony z rachunku wyników za dany okres,

- dynamicznym, odnoszącym się do określonego przedziału czasowego; dane do analizy w tym ujęciu zawiera rachunek przepływów pieniężnych, będący zestawieniem prezentującym rzeczywiste przepływy pieniężne w jednostce w konkretnym okresie (Dudycz 2011, s. 56-65; Nowak 2014, s. 222; Podstawy finansów... 2015, s. 160; Finanse przedsiębiorstwa... 2015, s. 43-47; Golej i Prędkiewicz 2015, s. 156-161).

Bilans i rachunek przepływów pieniężnych stanowią najważniejsze źródła danych do obliczenia wskaźników płynności. Analiza płynności przeprowadzona na podstawie rachunku przepływów pieniężnych obrazuje gospodarkę pieniężną przedsiębiorstwa oraz uzupełnia informacje o płynności wynikające z analizy 
bilansu. Obie te analizy mają zaś dostarczyć danych na temat racjonalnego zarządzania płynnością.

\subsection{Statyczne wskaźniki płynności finansowej}

Właściwe zarządzanie przedsiębiorstwem wymaga stałej wiedzy o kształtowaniu się jego płynności finansowej. Najczęściej stosowane metody oceny płynności opierają się na wskaźnikach statycznych, pozwalających zarządom firm poprawnie diagnozować ich bieżącą sytuację finansową pod kątem obsługi zadłużenia oraz perspektyw dalszego działania. Pomiar poziomu płynności finansowej wykorzystywany jest także przez banki do oceny sytuacji finansowej kredytobiorców przy podejmowaniu decyzji o udzieleniu kredytu. W literaturze przedmiotu wyróżnia się trzy elementarne wskaźniki statyczne, mające powszechne zastosowanie z powodu swojej prostoty (Dudycz 2011, s. 61; Nowak 2014, s. 222, Gabrusewicz 2014, s. 331-338; Analiza finansowa... 2016, s. 172-179):

- wskaźnik płynności bieżącej (wskaźnik płynności III stopnia),

- wskaźnik płynności szybkiej (wskaźnik płynności II stopnia),

- wskaźnik płynności natychmiastowej (wskaźnik płynności I stopnia).

Badanie płynności w ujęciu statycznym dokonywane jest na podstawie danych bilansowych przedstawiających wielkości na określony dzień. Wskaźniki statyczne nie informują o kształtowaniu się płynności finansowej w całym okresie sprawozdawczym, lecz jedynie o jej poziomie w określonym dniu (Finanse przedsiębiorstwa... 2015, s. 43). Ocena statyczna ma charakter ograniczony. Istotą badania płynności przy użyciu mierników statycznych jest porównanie ich wartości do zalecanych norm, ale specyfika branżowych aktywów obrotowych powinna być uwzględniana w ocenie ich płynności. Konstrukcja wskaźników statycznych pozwala na obserwację zmian poziomu płynności w czasie i porównywanie ich wielkości pomiędzy jednostkami.

Wskaźnik płynności bieżącej (current ratio) opisuje wzór:

$$
\text { wskaźnik płynności bieżącej }=\frac{\text { aktywa obrotowe }}{\text { zobowiązania bieżące }} \text {. }
$$

Wskaźnik płynności bieżącej wyraża zdolność przedsiębiorstwa do regulowania zaległych zobowiązań krótkoterminowych na dzień pomiaru. Wskaźnik ten określa stan posiadanych przez przedsiębiorstwo środków pieniężnych i zapasów oraz wartość należności i zobowiązań krótkoterminowych. Aktywa obrotowe powinny składać się tylko z elementów możliwych do spieniężenia. Wskaźnik określa, ile razy aktywa bieżące pokrywają zobowiązania bieżące. Prawidłowy poziom tego wskaźnika zawiera sie w przedziale od 1,2 do 2. Wysoki poziom wskaźnika płynności bieżącej może oznaczać nadpłynność finansową jednostki, 
a jego niski poziom - problemy z płynnością. Takie sytuacje mogą być spowodowane niewłaściwym zarządzaniem bieżącymi aktywami i pasywami.

Wskaźnik płynności szybkiej (quick ratio) jest wyrażony wzorem:

$$
\text { wskaźnik płynności szybkiej = } \frac{\text { aktywa obrotowe }- \text { zapasy }}{\text { zobowiązania bieżące }} \text {. }
$$

Wskaźnik ten określa stopień pokrycia bieżących zobowiązań przedsiębiorstwa najbardziej płynnymi aktywami obrotowymi, informuje więc, ile złotych, wyrażonych sumą aktywów łatwo wymienialnych na gotówkę, daje gwarancję spłaty jednego złotego zobowiązań pozostających do uregulowania w ciągu roku. Konstrukcja wskaźnika płynności II stopnia jest oparta na identycznych zasadach jak wskaźnika płynności III stopnia, ale aktywa bieżące są obwarowane większą szybkością ich przekształcenia w gotówkę (Wędzki 2015, s. 167). Norma dla wskaźnika płynności szybkiej oscyluje wokół 1,0. Niższa od wielkości normatywnej wartość tego wskaźnika może sygnalizować problemy w spłacie zobowiązań, a zbyt wysoka - nieproduktywne gromadzenie środków na rachunkach bankowych lub utrzymywanie wysokiego stanu należności.

Wskaźnik płynności natychmiastowej (gotówkowej) (instant liquidity ratio, cash liquidity ratio) oblicza się za pomocą wzoru:

$$
\text { wskaźnik płynności natychmiastowej }=\frac{\text { środki pieniężne }}{\text { zobowiązania bieżące }} \text {. }
$$

Wskaźnik płynności natychmiastowej najczęściej jest uzupełnieniem pozostałych wskaźników statycznych. Wskaźnik płynności I stopnia informuje, ile razy gotówka i jej ekwiwalenty zabezpieczają spłatę zobowiązań bieżących (Wędzki 2015, s. 169). Najczęściej podawaną normą wskaźnika płynności gotówkowej jest 0,2 . Niski poziom tego wskaźnika nie oznacza braku płynności i wynika z reguł zarządzania środkami pieniężnymi, zgodnie z którymi stan środków utrzymywanych w przedsiębiorstwie powinien być ograniczony do minimum, gdyż wyłącznie aktywa zaangażowane w obrót są źródłem korzyści. Nadmiar środków pieniężnych sprzyja powstawaniu kosztów utraconych możliwości uwarunkowanych wysokością rynkowych stóp procentowych (Zaleska 2012, s. 76). Wskaźnik płynności natychmiastowej charakteryzuje się dużą wrażliwością na niespodziewane wpływy lub wydatki, a zatem i zmiennością, przez co nie odzwierciedla prawdziwego poziomu płynności finansowej w przedsiębiorstwie.

Zaprezentowane wskaźniki statyczne nie stanowią idealnych mierników płynności. Pomimo częstego stosowania tych wskaźników cechuje je wiele wad, takich jak nieuwzględnienie zobowiązań pozabilansowych oraz niedostateczne określenie wymagalności zobowiązań krótkoterminowych i płynności krótkoterminowych należności. Wady wskaźników statycznych wynikają ponadto z możliwości kształtowania poziomu płynności przez politykę zaopatrzenia, wybór momentu 
bilansowego lub inne rozstrzygnięcia polityki bilansowej, a także zaciągnięcie lub prolongatę kredytu krótkoterminowego. Wskaźniki statyczne nie stwarzają podstaw do charakterystyki oraz szacowania przyszłych wpływów i wydatków.

\subsection{Dynamiczne wskaźniki płynności finansowej}

Miary płynności finansowej oparte na informacjach pochodzących z bilansu nie wyrażają zdolności płatniczych przedsiębiorstwa. Z tego względu poza statycznymi metodami pomiaru płynności wykorzystuje się wskaźniki dynamiczne obliczane na podstawie informacji zawartych w rachunku przepływów pieniężnych. Dynamiczna ocena płynności pozwala uzyskać bardziej szczegółowe dane o realnej kondycji finansowej przedsiębiorstwa. Stanowi ona rozwinięcie badania dokonanego z wykorzystaniem danych bilansowych. Poziom płynności finansowej obliczany jest na podstawie ukształtowanych sald przepływu środków pieniężnych, wykazanych w rachunku tych przepływów. Rachunek odzwierciedla wielkość wygenerowanej gotówki, wykorzystywanej m.in. do regulowania zobowiązań bieżących. Dynamiczne metody oceny płynności, które opierają się na informacjach pochodzących z rachunku przepływów pieniężnych, pogrupowane są jako (Finanse przedsiębiorstwa... 2015, s. 45):

- wskaźniki wystarczalności gotówkowej,

- wskaźniki wydajności gotówkowej,

- wskaźniki struktury przepływów pieniężnych.

Przytoczone wskaźniki dynamiczne odznaczają się wieloprofilowym charakterem, służącym do prawidłowej oceny możliwości finansowych przedsiębiorstwa. Mogą być porównywane z danymi z okresów ubiegłych, wskaźnikami konkurentów na rynku, średnimi wskaźnikami branżowymi oraz wskaźnikami planowanymi. Są zgodne z zasadą kasową dotyczącą ujmowania w księgach wartości zdarzenia ekonomicznego w momencie wystąpienia rzeczywistego przepływu gotówki. Dla dynamicznych mierników płynności finansowej nie istnieją ustalone wielkości standardowe.

Wskaźniki wystarczalności gotówkowej są podstawą oceny zdolności kreowania przez przedsiębiorstwo środków pieniężnych z działalności operacyjnej na pokrycie inwestycji w aktywach trwałych, wypłatę dochodów z kapitału i regulację zobowiązań (Gabrusewicz 2014, s. 339). Innymi słowy, informują one o stopniu obciążenia środków z podstawowej działalności wydatkami na nabycie niefinansowych składników majątku trwałego, wypłatę dywidend dla właścicieli i spłatę zadłużenia. Analiza tych wskaźników jest szczególnie przydatna do weryfikacji możliwości płatniczych przedsiębiorstwa, a ich konstrukcja pozwala je bardziej uszczegóławiać. Wyższy poziom tych wskaźników świadczy o możliwości wyasygnowania większej puli środków pieniężnych na realizację innych 
potrzeb płatniczych. Dodatnia wartość upewnia o wystarczalności przychodów na pokrycie wzrostu kapitału pracującego i regulowanie wydatków kosztowych. Ważny w tej grupie jest wskaźnik wystarczalności gotówkowej na spłatę długów ogółem (cash adequacy ratio for the repayment of total debts) wyrażony wzorem:

$\begin{gathered}\text { wskaźnik wystarczalności gotówkowej } \\ \text { na spłatę długów ogółem }\end{gathered}=\frac{\text { środki pieniężne z działalności operacyjnej }}{\text { zobowiązania ogółem }}$.

Wskaźnik ten informuje o zdolności przedsiębiorstwa do spłaty zobowiązań. Wskaźnik relatywnie niższy świadczy o wyższym udziale zobowiązań długoterminowych w całości zobowiązań. W niektórych sytuacjach wskaźnik wystarczalności gotówkowej na spłatę długów ogółem wykorzystywany jest do przewidywania bankructwa przedsiębiorstw. Jego odwrotność, czyli relacja zobowiązań ogółem do wartości gotówki wytworzonej w działalności operacyjnej, odzwierciedla okres, z upływem którego przedsiębiorstwo byłoby w stanie uregulować zobowiązania środkami pieniężnymi pochodzącymi z podstawowej działalności. Wskaźnik ten mierzy płynność finansową przedsiębiorstwa, informując o faktycznych możliwościach spłaty ogółu zobowiązań z wykreowanych wpływów (Podstawy zarzq̨zania płynnościq... 2010, s. 106). Wartość wskaźnika powyżej 1,0 świadczy o tym, że podmiot nie musi korzystać z zewnętrznych źródeł finansowania.

Inna grupa dynamicznych wskaźników płynności mierzy wydajność gotówkową. Wskaźniki te informują o stosunku środków pieniężnych wypracowanych w ramach podstawowej działalności przedsiębiorstwa do przychodów ze sprzedaży, zysku operacyjnego lub zasobów majątku (Gabrusewicz 2014, s. 338). Wzrost ich wartości dowodzi poprawy sytuacji i płynności przedsiębiorstwa. Wskaźniki te wyrażają efektywność gotówkową prowadzonej działalności. Z uwagi na uwzględnianie zysku kasowego, zamiast memoriałowego, określa się je jako pieniężne odpowiedniki wskaźników rentowności. Wskaźniki wydajności gotówkowej ilustrują zależności zachodzące pomiędzy przepływami gotówkowymi a głównymi kategoriami bilansu i rachunku zysków oraz strat. W grupie wskaźników wydajności gotówkowej szczególnie ważny jest wskaźnik wydajności gotówkowej majątku (cash efficiency rate, cash flow return on assets ratio) obliczany za pomocą wzoru:

$\begin{gathered}\text { wskaźnik wydajności gotówkowej } \\ \text { majątku }\end{gathered}=\frac{\text { środki pieniężne z działalności operacyjnej }}{\text { średnia wartość majątku ogółem }}$.

Wskaźnik ten określa, ile środków pieniężnych z działalności operacyjnej zostało wytworzonych z jednego złotego majątku ogółem. Mierzy on zdolności aktywów jednostki do kreowania środków pieniężnych (Podstawy zarzqdzania płynnościq... 2010, s. 105). Określany jest jako produktywność gotówkowa 
aktywów. Kształtowanie się wskaźnika wydajności gotówkowej majątku na coraz wyższym poziomie jest zjawiskiem pożądanym oraz ocenianym pozytywnie.

Wskaźniki struktury przepływów pieniężnych prezentują udział określonych składników rachunku przepływów pieniężnych w wygospodarowanej nadwyżce pieniężnej. Badanie tej grupy wskaźników wiąże się ze wstępną analizą, która polega na przygotowaniu do badań właściwych. Jednym z najważniejszych wskaźników struktury przepływów pieniężnych jest wskaźnik udziału zysku netto $\mathrm{w}$ środkach pieniężnych netto $\mathrm{z}$ działalności operacyjnej (the ratio of net profit in net cash from operating activities) obliczany w następujący sposób:

$\begin{gathered}\text { wskaźnik udziału zysku netto w środkach } \\ \text { pieniężnych netto z działalności operacyjnej }\end{gathered}=\frac{\text { zysk netto }}{\begin{array}{c}\text { środki pieniężne netto z działalności } \\ \text { operacyjnej }\end{array}}$.

Wskaźnik ten wyraża relację wyniku finansowego ujętego memoriałowo do wielkości przepływów pieniężnych wykreowanych z podstawowej działalności firmy. Jest to stosunek wyniku memoriałowego do wyniku kasowego. Kształtowanie się wskaźnika udziału zysku netto w środkach pieniężnych netto z działalności operacyjnej poniżej wartości 1,0 świadczy o występowaniu operacji, które mimo niepowodowania wypływu gotówki wpływają na obniżenie wyniku finansowego netto. Wskaźnik ten określa faktyczny udział zysku netto w działalności operacyjnej.

Cechą dynamicznego podejścia do pomiaru płynności finansowej przedsiębiorstwa jest retrospektywność, ponieważ mierzeniu podlegają rezultaty skumulowanych, przeszłych zdarzeń gospodarczych, ilustrując pieniężną gospodarkę przedsiębiorstwa. $\mathrm{Z}$ tego względu pomiar dynamiczny jest bardziej odpowiedni do oceny płynności finansowej długoterminowej (Dudycz 2011, s. 60).

Statyczne oraz dynamiczne wskaźniki płynności obliczone na podstawie publikowanych sprawozdań, w tym szczególnie bilansów i rachunków przepływów pieniężnych, są wiarygodnymi nośnikami informacji na temat płynności finansowej oraz pozwalają szybko i w sposób miarodajny ocenić stan i strategię płynności przedsiębiorstwa. W porównaniu z innymi grupami wskaźników bazują one na łatwo dostępnych informacjach, co stanowi ich przewagę nad bardziej wyspecjalizowanymi wskaźnikami pozwalającymi określić sytuację finansową przedsiębiorstwa.

Uważa się, że dynamiczne wskaźniki płynności oparte na przyszłych strumieniach pieniężnych lepiej odwzorowują sytuację finansową jednostki niż wskaźniki statyczne. Pomiarem dynamicznym można objąć okresy minione i nadchodzące, gdyż bada się według rodzajów działalności przepływy wykazane w rachunku cash flow, uwzględnia je w bieżącym sterowaniu płynnością i prognozuje ich przyszłe wartości. 


\section{Płynność finansowa PKN Orlen SA w latach 2013-2016}

Do prezentacji zakresu danych i informacji o płynności finansowej w artykule wybrano sprawozdania jednostkowe Polskiego Koncernu Naftowego Orlen SA z lat 2013-2016 ${ }^{5}$. PKN Orlen SA jest podmiotem zaklasyfikowanym do sektora paliwowego. Wyniki analiz zaprezentowano w tabelach $1-6$. W tabeli 1 zestawiono przepływy pieniężne PKN Orlen SA za lata 2013-2016 w przekroju działalności: operacyjnej, inwestycyjnej i finansowej.

Tabela 1. Przepływy pieniężne PKN Orlen SA w latach 2013-2016 (w mln zł)

\begin{tabular}{|l|c|c|c|c|}
\hline \multicolumn{1}{|c|}{ Rodzaj działalności } & 2013 & 2014 & 2015 & 2016 \\
\hline Działalność operacyjna & 4370 & 2217 & 948 & 5434 \\
\hline Działalność inwestycyjna & -1578 & -2401 & -1669 & -1873 \\
\hline Działalność finansowa & -1691 & 1592 & -1796 & -1970 \\
\hline
\end{tabular}

Źródło: opracowanie własne na podstawie danych zawartych w jednostkowych sprawozdaniach finansowych PKN Orlen SA z lat 2013-2016.

Środki pieniężne netto z działalności operacyjnej w 2014 r. wyniosły 2217 mln zł. Według sprawozdania zarządu spółki wartość ta spowodowana była głównie dodatnim wpływem zmniejszenia kapitału pracującego netto, który skompensował stratę netto powiększoną o wartość amortyzacji. W stosunku do $2013 \mathrm{r}$. wartość przepływów pieniężnych z działalności operacyjnej uległa zmniejszeniu o 2153 mln zł, czyli o 49,27\%. Znaczący spadek wartości przepływów środków pieniężnych z podstawowej działalności odnotowano również w 2015 r., gdyż w stosunku do 2014 r. nastąpił spadek ich wartości o $1269 \mathrm{mln}$ zł, tj. o 57,24\%. Przepływy środków pieniężnych netto z działalności operacyjnej w 2015 wynosiły 948 mln zł i obejmowały w szczególności zysk EBITDA, ujemny efekt zwiększenia kapitału pracującego netto oraz ujemne różnice kursowe netto. Rok 2016 zamknął się ok. 6-krotnym zwiększeniem wartości przepływów pieniężnych do wysokości $5434 \mathrm{mln}$ zł, czyli o $4486 \mathrm{mln}$ zł więcej niż w roku poprzednim. Wpływ na to miał dodatni efekt zmniejszenia kapitału pracującego netto, głównie wskutek wzrostu zobowiązań z tytułu zakupu ropy i biokomponentów oraz zobowiązań podatkowych przy jednoczesnym zwiększeniu należności z tytułu dostaw i usług.

Innym sposobem określenia sytuacji finansowej przedsiębiorstwa na podstawie rachunku przepływów pieniężnych jest porównanie osiągniętego wyniku finansowego netto z przepływami pieniężnymi netto z działalności operacyjnej. Zesta-

5 Jednostkowe sprawozdania finansowe sporządzane są na mocy Ustawy z dnia 29 września 1994 r.... 
wienie takich danych wykazanych przez PKN Orlen SA w latach 2013-2016 stanowi tabela 2.

Tabela 2. Relacje między wynikiem finansowym netto a przepływami pieniężnymi netto z działalności operacyjnej w PKN Orlen SA w latach 2013-2016 (w mln zł)

\begin{tabular}{|l|c|c|c|c|}
\hline \multicolumn{1}{|c|}{ Wyszczególnienie } & 2013 & 2014 & 2015 & 2016 \\
\hline Przepływy z działalności operacyjnej & 4370 & 2217 & 948 & 5434 \\
\hline Wynik finansowy netto & 618 & -4672 & 1048 & 5364 \\
\hline
\end{tabular}

Źródło: opracowanie własne na podstawie danych zawartych w jednostkowych sprawozdaniach finansowych PKN Orlen SA z lat 2013-2016.

W 2013 r. przedsiębiorstwo odnotowało dodatnie przepływy pieniężne z podstawowej działalności przy jednoczesnym osiągnięciu zysku, co należy uznać za sytuację korzystną. Przepływy pieniężne z działalności operacyjnej w dwóch kolejnych latach znacznie się obniżały, mimo to utrzymywane były ich dodatnie wartości. Dopiero w 2016 r. nastąpił wspomniany duży ich wzrost.

W 2014 r. nastąpiło znaczące zmniejszenie wyniku finansowego netto - odnotowano w stosunku do roku poprzedniego spadek wynoszący $5290 \mathrm{mln}$ zł. Za 2015 r. osiągnięto zysk netto w wysokości $1048 \mathrm{mln}$ zł, co oznacza wzrost wyniku finansowego w stosunku do 2014 r. o 5720 mln zł. W 2015 r. osiągnięto najkorzystniejszą z możliwych relację między wynikiem finansowym a przepływami pieniężnymi netto pochodzącymi z działalności operacyjnej. W 2016 r. sama ta relacja była mniej korzystna mimo ogromnego pod względem wartości wzrostu zarówno przepływów pieniężnych, jak i wyniku finansowego netto.

Statyczna analiza płynności finansowej dla PKN Orlen SA opiera się na bilansie jednostkowym. Podstawą prawidłowej analizy jest relacja majątku obrotowego (lub jego części) do zobowiązań krótkoterminowych. Niezbędne dane do obliczenia statycznych wskaźników płynności za lata 2013-2016 zawiera tabela 3.

Tabela 3. Wybrane wartości bilansu PKN Orlen SA z lat 2013-2016 (w mln zł)

\begin{tabular}{|l|c|c|c|c|}
\hline \multicolumn{1}{|c|}{ Pozycja bilansu } & 2013 & 2014 & 2015 & 2016 \\
\hline Aktywa obrotowe & 18708 & 16176 & 13835 & 17963 \\
\hline Zapasy & 9383 & 6497 & 7715 & 7309 \\
\hline Środki pieniężne & 2072 & 3475 & 964 & 2563 \\
\hline Zobowiązania krótkoterminowe & 12005 & 10297 & 9676 & 11986 \\
\hline
\end{tabular}

Źródło: opracowanie własne na podstawie danych zawartych w jednostkowych sprawozdaniach finansowych PKN Orlen SA z lat 2013-2016. 
Aktywa obrotowe, w tym również zapasy, były najwyższe w 2013 r. i wynosiły odpowiednio $18708 \mathrm{mln}$ zł i $9383 \mathrm{mln}$ zł. W kolejnych dwóch latach aktywa te zmniejszały się: o 2532 mln zł w 2014 r. (tj. o 13,5\%) i o $2341 \mathrm{mln}$ zł w 2015 r. (najniższa wartość), tj. o 14,5\% w stosunku do roku poprzedniego. W 2016 r. aktywa obrotowe wzrosły w porównaniu z 2015 r. o 4128 mln zł, czyli o ok. 30\%, ale nie osiągnęły stanu z 2013 r. Zapasy w 2014 r. obniżyły się o 2886 mln zł, czyli o ok. $31 \%$ w stosunku do 2013 r., i był to najniższy ich stan w badanym okresie. W 2015 r. zapasy wzrosły o 1218 mln zł, tj. o ok. 19\% w stosunku do 2014 r., a w 2016 r. nastąpił ich niewielki spadek o 406 mln zł, tj. o 5,3\% w stosunku do 2015 r. Najwyższy stan środków pieniężnych, 3475 mln zł, odnotowano w 2014 r., a najniższy, 964 mln zł, w 2015 r. W 2016 r. wartość środków pieniężnych zwiększyła się o 1599 mln zł, tj. o ok. 166\% w stosunku do 2015 r. Najwyższe zobowiązania krótkoterminowe, 12005 mln zł, odnotowano w 2013 r., w 2014 r. nastąpił ich spadek o 1708 mln zł, tj. o 14,23\% w stosunku do 2013 r., a w 2015 r. również spadek - o $621 \mathrm{mln}$ zł, tj. o 6\% w stosunku do 2014 r. W 2016 r. nastąpił wzrost tych zobowiązań o 2310 mln zł, tj. o ok. 24\% w stosunku do 2015 r. Podane wielkości zdeterminowały wartości statycznych wskaźników płynności przedstawione w tabeli 4 .

Tabela 4. Statyczne wskaźniki płynności PKN Orlen SA w latach 2013-2016

\begin{tabular}{|l|c|c|c|c|}
\hline \multicolumn{1}{|c|}{ Wskaźnik } & 2013 & 2014 & 2015 & 2016 \\
\hline Wskaźnik płynności bieżącej & 1,56 & 1,57 & 1,43 & 1,50 \\
\hline Wskaźnik płynności szybkiej & 0,78 & 0,94 & 0,63 & 0,89 \\
\hline Wskaźnik płynności natychmiastowej & 0,17 & 0,34 & 0,10 & 0,21 \\
\hline
\end{tabular}

Źródło: opracowanie własne na podstawie danych zawartych w jednostkowych sprawozdaniach finansowych PKN Orlen SA z lat 2013-2016.

Wskaźnik płynności bieżącej wyniósł 1,57 w 2014 r. i był najwyższy w badanym okresie. W 2013 r. osiągnął wartość 1,56, tzn. był minimalnie niższy niż w 2014 r. Spadek wskaźnika płynności bieżącej do poziomu 1,43 i 1,50 odnotowano kolejno w 2015 r. i 2016 r. Mimo niewielkich wahań wartość wskaźnika mieści się w przyjętych normach. Warto zaznaczyć, że w celu optymalizacji kosztów finansowych i efektywnego zarządzania bieżącą płynnością finansową PKN Orlen SA wykorzystuje system koncentracji środków finansowych, nazywany inaczej systemem cash-poolingu lub cash pool.

Najbardziej płynne aktywa obrotowe spółki w 2013 r. pokryły jej zobowiązania krótkoterminowe w wysokości 0,78, czyli w 78\%. W 2014 r. wskaźnik płynności II stopnia wyniósł 0,94 i był wyższy o 0,16, a więc o 16 p.p. w stosunku do 2013 r. W 2015 r. wskaźnik płynności szybkiej wyniósł 0,63 i obniżył się w stosunku do 
2014 r. o 0,31, czyli o 31 p.p., odbiegając znacznie od wartości normatywnej 1,0 i sugerując niewielkie problemy z płynnością finansową spółki, jednak już w roku następnym wzrósł do 0,89 . W zarządzaniu płynnością finansową jednostka dominująca, czyli PKN Orlen SA, może sama emitować i nabywać obligacje emitowane przez spółki z grupy Orlen.

W latach 2013-2016 wskaźnik płynności gotówkowej ulegał widocznym zmianom. W 2013 r. ukształtował się na poziomie 0,17. W 2014 r. jego wartość wzrosła dwukrotnie, do 0,34 , z czego wynika, że w tym roku środki pieniężne wraz z ich ekwiwalentami zabezpieczyły spłatę zobowiązań bieżących w $34 \%$. W 2015 r. wskaźnik płynności I stopnia wyniósł 0,10 i w stosunku do 2014 r. zmniejszył się o 0,24, czyli o 24 p.p. W 2016 r. wzrósł ponownie, ale tylko do poziomu 0,21. Mimo zmian wskaźnika płynności gotówkowej jego wartość w badanym okresie oscyluje wokół wielkości normatywnej.

Na podstawie danych zaprezentowanych w tabelach 3 i 4 można zauważyć, że płynność finansowa PKN Orlen SA w dwóch pierwszych latach badanego okresu przyjmowała wartości mieszczące się w przyjętych normach. W 2015 r. wartość wszystkich wskaźników statycznych znacząco spadła, lecz w 2016 r. ponownie wzrosła, co miało odzwierciedlenie we wzroście płynności finansowej spółki.

Dla pełnego ukazania płynności finansowej PKN Orlen SA badanie statyczne należy uzupełnić analizą w ujęciu dynamicznym. Wielkości liczbowe do obliczenia wybranych wskaźników dynamicznych przedstawia tabela 5.

Tabela 5. Wybrane wielkości z jednostkowego sprawozdania finansowego PKN Orlen SA za lata 2013-2016 (w mln zł)

\begin{tabular}{|l|c|c|c|c|c|}
\hline \multicolumn{1}{|c|}{ Wielkości sprawozdawcze } & 2012 & 2013 & 2014 & 2015 & 2016 \\
\hline $\begin{array}{l}\text { Środki pieniężne z działalności opera- } \\
\text { cyjnej }\end{array}$ & 2065 & 4370 & 2217 & 948 & 5434 \\
\hline Zobowiązania ogółem & 18487 & 18928 & 21676 & 19135 & 20904 \\
\hline Aktywa ogółem & 41407 & 42063 & 37978 & 36981 & 43072 \\
\hline Wynik finansowy netto & 2128 & 618 & -4672 & 1048 & 5364 \\
\hline
\end{tabular}

Źródło: opracowanie własne na podstawie danych zawartych w jednostkowych sprawozdaniach finansowych PKN Orlen SA z lat 2013-2016.

Analiza danych zawartych w tabeli 5 pokazuje, że przepływy osiągane przez jednostkę z jej podstawowej działalności, a także posiadane aktywa obniżały się z roku na rok, poczynając od 2013 r. aż do 2016 r., w którym znacząco wzrosły. Spółka przez cały badany okres utrzymywała dodatni poziom przepływów pieniężnych z działalności operacyjnej. Jednym z instrumentów wykorzystywanych do efektywnego zarządzania finansami PKN Orlen SA są transakcje sprzedaży części obowiązkowych zapasów ropy naftowej przy jednoczesnym zawie- 
raniu umów na ich utrzymanie oraz faktoring należności. Zadłużenie w ciągu analizowanego okresu ulegało nieznacznym zmianom. Wartość wskaźników płynności obliczonych na podstawie danych z tabeli 5 zaprezentowano w tabeli 6 .

Tabela 6. Dynamiczne wskaźniki płynności PKN Orlen SA w latach 2013-2016

\begin{tabular}{|l|c|c|c|c|}
\hline \multicolumn{1}{|c|}{ Wskaźnik } & 2013 & 2014 & 2015 & 2016 \\
\hline $\begin{array}{l}\text { Wskaźnik wystarczalności gotówkowej } \\
\text { na spłatę zobowiązań ogółem }\end{array}$ & 0,23 & 0,10 & 0,05 & 0,26 \\
\hline $\begin{array}{l}\text { Wskaźnik wydajności gotówkowej } \\
\text { majątku }\end{array}$ & 0,10 & 0,06 & 0,03 & 0,14 \\
\hline $\begin{array}{l}\text { Wskaźnik udziału zysku netto w środ- } \\
\text { kach pieniężnych netto z działalności } \\
\text { operacyjnej }\end{array}$ & 0,14 & $-2,11$ & 1,11 & 0,99 \\
\hline
\end{tabular}

Źródło: opracowanie własne na podstawie danych zawartych w jednostkowych sprawozdaniach finansowych PKN Orlen SA z lat 2013-2016.

Kształtowanie się wskaźnika wystarczalności gotówkowej na spłatę zobowiązań dowodzi, że poza środkami z podstawowej działalności w celu uregulowania ogółu swoich zobowiązań spółka musi korzystać z zewnętrznych źródeł finansowania. Zauważalna jest tendencja spadkowa tego wskaźnika w latach 2014-2015, jednak w 2016 r. jego wartość wzrosła do poziomu nieco wyższego niż w $2013 \mathrm{r}$.

Wskaźnik wydajności gotówkowej majątku w 2013 r. wyniósł 0,1, a w dwóch kolejnych latach stopniowo malał. W 2014 r. z jednego złotego majątku ogółem zostało wygenerowane zaledwie 0,06 zł, co oznacza spadek wartości wskaźnika o 0,04, tj. o 40\% w stosunku do 2013 r. W 2015 r. produktywność gotówkowa aktywów wyniosła 0,03, czyli o 0,03 mniej niż w 2014 r. Spadek wartości wskaźnika wydajności gotówkowej jest zjawiskiem negatywnym i niepożądanym. W 2016 r. wartość ta wzrosła do 0,14, przekraczając o 0,04 poziom z 2013 r. Była to najwyższa wartość tego wskaźnika w badanym okresie.

W 2013 r. udział zysku netto w środkach pieniężnych netto z działalności operacyjnej wyniósł 0,14 . W porównaniu z 2014 r., w którym wystąpiła strata netto w wysokości -4672 mln zł, była to wartość większa o 2,25. W 2015 r. w stosunku do 2014 r. nastąpił znaczący wzrost wyniku finansowego netto, przez co wskaźnik udziału zysku netto w środkach pieniężnych netto z działalności operacyjnej ukształtował się na poziomie 1,11, a w 2016 r. nieco się obniżył do 0,99 . Wartości te informują, ile złotych zysku netto przypada na jeden złoty gotówki operacyjnej, a oscylując wokół $1 \mathrm{w}$ ostatnich latach, wskazują na zbieżność zysku memoriałowego z gotówką wykreowaną z działalności operacyjnej (zyskiem kasowym). $\mathrm{Z}$ informacji wykazanych w jednostkowych sprawozdaniach 
z przepływów pieniężnych można wnioskować, że dynamiczne zmiany tego wskaźnika były spowodowane zmianami zarówno wielkości przepływów pieniężnych z działalności operacyjnej, jak i wyniku finansowego netto.

\section{Podsumowanie}

W artykule przedstawiono analizę płynności finansowej na przykładzie PKN Orlen SA w latach 2013-2016. Jest to podmiot gospodarczy o wysokiej rentowności i stabilnej pozycji na rynku, wzbudzający zaufanie banków oraz inwestorów. Celem analizy płynności finansowej jest, jak już wspomniano, zweryfikowanie możliwości wywiązywania się przedsiębiorstwa z zaciągniętych zobowiązań bieżących (krótkoterminowych) przy zachowaniu ustalonych terminów ich spłaty, a także ocena posiadania płynności finansowej, tzn. dysponowania odpowiednim zasobem środków pieniężnych gwarantujących bieżące spłaty. $Z$ analizą płynności wiąże się również możliwość zdiagnozowania aktualnej sytuacji finansowej przedsiębiorstwa. Prawidłowe zarządzanie płynnością warunkuje kontynuację działalności. W ocenie analityków płynność finansowa jest ważniejsza niż zysk i majątek.

Analizę płynności finansowej w PKN Orlen SA przeprowadzono na podstawie kształtowania się przepływów pieniężnych oraz wskaźników płynności finansowej. Wskaźniki płynności finansowej są miarodajnym narzędziem oceny zdolności jednostki do bieżącego regulowania zobowiązań. Analiza przepływów pieniężnych pozwoliła ocenić płynność finansową PKN Orlen SA. Ogólna relacja wyniku finansowego netto do przepływów pieniężnych z działalności operacyjnej netto wykazała, że spółka przez większość analizowanego okresu osiągała zysk przy dodatnich przepływach pieniężnych ze swojej podstawowej działalności.

Płynność finansową PKN Orlen SA oceniono najpierw na podstawie wskaźników statycznych, obliczonych przy użyciu wielkości pochodzących z bilansów. Są to wskaźniki: płynności bieżącej (relacja aktywów obrotowych do zobowiązań krótkoterminowych), płynności szybkiej (aktywa obrotowe zmniejszone o zapasy i czynne rozliczenia międzyokresowe do zobowiązań krótkoterminowych) oraz płynności gotówkowej (inwestycje krótkoterminowe do zobowiązań krótkoterminowych), a wymagane ich wartości wynoszą odpowiednio 1,2-1,6; 0,8-1,2 i 0,2. Wykazano, że wskaźniki te w przypadku PKN Orlen SA w badanym okresie kształtowały się na poziomie ogólnie przyjętych norm. Jedynie w 2015 r. wartość wskaźników spadła, lecz w 2016 r. ponownie nastąpił wzrost wszystkich badanych wskaźników. Należy zaznaczyć przy tym, że statyczne wskaźniki obrazują płynność finansową podmiotu na określony moment bilansowy. 
Dynamiczną analizę płynności przeprowadzono, opierając się na wskaźnikach obliczonych na podstawie sprawozdania z przepływów pieniężnych. Wartość wskaźnika wystarczalności gotówkowej na spłatę długów ogółem wahała się w badanym okresie od 0,23 w 2013 r. do 0,26 w 2016 r. (w 2014 r. i 2015 r. wynosiła ona odpowienio tylko 0,10 i 0,05). Dane te świadczą o konieczności korzystania przez PKN Orlen SA z zewnętrznych źródeł finansowania. Kształtowanie się wskaźnika wydajności gotówkowej majątku w badanym okresie, zwłaszcza w latach 2014-2015, również nie może być ocenione pozytywnie. Spółka powinna dążyć do zwiększenia przepływów pieniężnych ze swojej podstawowej działalności, a tym samym do zwiększenia produktywności majątku. Poziom wskaźnika udziału zysku netto w środkach pieniężnych netto z działalności operacyjnej spółki ulegał zmianom. Zwiększenie jego wartości w 2015 r. w porównaniu z 2014 r. należy uznać za zjawisko pozytywne. Płynność finansowa PKN Orlen SA w latach 2013-2016 nie zagrażała prawidłowemu funkcjonowaniu spółki. W kolejnych latach spółka powinna jednak dążyć do poprawy przedstawionych wskaźników.

Analiza przeprowadzona na przykładzie PKN Orlen SA pozwoliła ocenić płynność finansową tej spółki. Możliwość szybkiej i rzetelnej analizy oraz oceny płynności finansowej stwarza szanse zwiększenia wartości przedsiębiorstwa zarówno w krótkim, jak i długim okresie. Kształtowanie płynności finansowej jest jednym z głównych elementów budowania przyszłości firmy, racjonalnego zarządzania jej finansami, wypłacalności, finansowania inwestycji i długoterminowego rozwoju. Utrzymanie właściwego poziomu płynności finansowej warunkuje prawidłowość i ciągłość prowadzonej działalności, zabezpiecza realizację celów i zadań jednostki, a także pozwala utrzymać lub wzmocnić jej pozycję na rynku. Obniżenie płynności finansowej lub jej brak przejawia się w zakłóceniach przebiegu bieżącej działalności, w petryfikacji czy niesprawności zasad i zakresu działań, które mogą prowadzić do konieczności reform lub bankructwa. Ranga płynności i jej funkcja w podejmowaniu właściwych decyzji menedżerskich i inwestorskich, kontroli sygnałów wczesnego ostrzegania, zabezpieczaniu kontynuacji działalności, sterowaniu bieżącymi przepływami pieniężnymi i zwiększaniu ich przyszłych wartości są niekwestionowane.

Istnieje antynomia między płynnością finansową a rentownością w przedsiębiorstwie. W literaturze przedmiotu wyrażony jest pogląd, że w perspektywie długookresowej to rentowność jest podstawą płynności finansowej, a nie na odwrót, ale wciąż nie docenia się wpływu dynamiki strumieni pieniężnych na wielkość stanów bilansowych (zasobowych). Studium przypadku PKN Orlen SA potwierdza, że płynność finansowa jest obecnie najważniejszym parametrem oceny przedsiębiorstwa, zapewnienia jego równowagi oraz stabilności dochodowej. Zagadnienie płynności finansowej obecne jest w literaturze przedmiotu z zakresu analizy, sprawozdawczości i nauk o zarządzaniu, a o znaczeniu płyn- 
ności finansowej świadczy niesłabnące zainteresowanie tym tematem nie tylko teoretyków, ale i praktyków gospodarczych. Mimo że płynność finansowa jest obszernie opisywana, a jej waga powszechnie znana, autorka niniejszego artykułu żywi nadzieję, że będzie on przyczynkiem do uwypuklenia roli płynności finansowej w ocenie przedsiębiorstwa.

\section{Literatura}

Analiza finansowa przedsiębiorstwa (2016), red. G. Gołębiowski, wyd. 2 zm., Difin, Warszawa.

Brigham E., Houston J. (2015), Zarzqdzanie finansami, Wydawnictwo Naukowe PWN, Warszawa.

Costea C.D., Hostiuc F. (2009), The Liquidity Ratios and Their Significance in the Financial Equilibrium of the Firms, „The Annals of The Stefan cel Mare University Suceava. Fascicle of The Faculty of Economics and Public Administration", vol. 9, nr 1(9).

Dudycz T. (2011), Analiza finansowa jako narzędzie zarzq̨dzania finansami przedsiębiorstwa, Indygo Zahir Media, Wrocław.

Finanse przedsiębiorstwa. Decyzje i efekty (2015), red. J. Grzywacz, Oficyna Wydawnicza Szkoły Głównej Handlowej w Warszawie, Warszawa.

Gabrusewicz W. (2014), Analiza finansowa przedsiębiorstwa. Teoria i zastosowanie, PWE, Warszawa.

Golej R., Prędkiewicz K. (2015), Analiza finansowa przedsiębiorstwa, Wydawnictwo Marina, Wrocław.

Michalski G. (2015), Strategiczne zarzqdzanie płynnościq finansowa w przedsiębiorstwie, wyd. 2 zm., CeDeWu, Warszawa.

Nowak E. (2014), Analiza sprawozdań finansowych, wyd. 3 zm., PWE, Warszawa.

Owolabi S.A., Obida S.S. (2012), Liquidity Management and Corporate Profitability: Case Study of Selected Manufacturing Companies Listed on the Nigerian Stock Exchange, „Business Management Dynamics”, vol. 2, nr 2.

Podstawy finansów przedsiębiorstw (2015), red. D. Ostrowska, E. Niedźwiedzka, Difin, Warszawa.

Podstawy zarzq̨dzania płynnościq finansowq przedsiębiorstwa (2010), red. T. Cicirko, Oficyna Wydawnicza Szkoły Głównej Handlowej w Warszawie, Warszawa.

Sierpińska M., Jachna T. (2004), Ocena przedsiębiorstwa według standardów światowych, Wydawnictwo Naukowe PWN, Warszawa.

Ustawa z dnia 29 września 1994 r. o rachunkowości, t.j., Dz.U. 2018, poz. 395, 398, z późn. zm.

Wąsowski W. (2011), Finanse spółki kapitałowej. Istota i warunki utrzymania płynności finansowej, „Przegląd Corporate Governance”, nr 1(25).

Wędzki D. (2015), Analiza wskaźnikowa sprawozdania finansowego według polskiego prawa bilansowego, wyd. 3 zm., Oficyna a Wolters Kluwer business, Warszawa.

Zaleska M. (2012), Ocena kondycji finansowej przedsiębiorstwa przez analityka bankowego, wyd. 2 zm., Oficyna Wydawnicza Szkoły Głównej Handlowej w Warszawie, Warszawa. 


\section{Financial Liquidity as a Leading Criterion for Evaluating an Enterprise} (Abstract)

The article discusses financial liquidity considered as a leading indicator of company performance. Financial liquidity is a function of shaping the proper relationship of receipts to expenditure in the management process. Its essence, methods of determination and analysis are presented on the basis of the balance sheet and cash flow statement, showing liquidity ratios, their classification and interpretation. The survey of financial liquidity in Polish companies was based on the example of unit financial statements of PKN Orlen SA. for the years 2013-2016. Cash flow and static and dynamic liquidity ratios were analysed. Research methods include a review of the literature on reporting, liquidity and financial analysis, interpretation of related legislation, analysis of financial statements, and inference. The results confirm that liquidity, which ensures a company's balance and stability, is today the most important parameter in assessing a company.

Keywords: financial liquidity, cash flow, liquidity ratios, corporate judgment. 